\title{
The Surrender of A Panoply of Copycats to The Case-Hardened Market Leader: Substantiation from An Experimental Study of The Indonesia Crop-Protection Industry
}

\begin{tabular}{|c|c|}
\hline & $\begin{array}{r}\text { Iwan GUNAWAN } \\
\text { Faculty of Economics and Business, University of Brawijaya } \\
\text { igun_18@yahoo.co.id }\end{array}$ \\
\hline $\begin{array}{l}\text { Submitted Date : } \\
16 \text { Maret } 2019\end{array}$ & $\begin{array}{r}\text { Achmad SUDIRO } \\
\text { Faculty of Economics and Business, University of Brawijaya }\end{array}$ \\
\hline Accepted Date & ppmem.brawijaya@ymail.com \\
\hline 9 April 2019 & $\begin{array}{r}\text { Ainur ROFIQ } \\
\text { Faculty of Economics and Business, University of Brawijaya } \\
\text { rofiq@ub.ac.id }\end{array}$ \\
\hline
\end{tabular}

Abstract

This study has three objectives: to reveal how to create effective copycats design; to determine the most favorable situation for copycats; to cognize the winner of panoplied copycats versus market leader. Study 1 with participation of 98 farmers revealed that copycats managed to steal quality image of market leader through imitation of typography and colour. Study 2 with involvement of 216 farmers suggested that copycat to situate farmer peers as referrals, apply moderately-lower pricing and persuade consumers without sales promotions. Market leader won against copycats in the battle for defending loyal consumers.

Keywords: Copycat; crop-protection market; low-literate consumers; pricing strategy; reference groups; sales promotions

\section{Introduction}

From the mid-1960s to early 2000, the crop-protection market has been supplied by brands from multinational companies. That changed with deregulation in 2001, which resulted in the availability of generic brands, most of which are copycats in the insecticide, fungicide or herbicide categories. These copycat brands (each in their own way) copied certain sections of the visual elements of the leader's packaging. Through simple observation that focuses only on brand-name imitation of products with two active ingredients, we found numerous copycats in the 2013 book of agriculture and forestry pesticides. Seventeen of 34 products with Profenofos as the active ingredient imitate the name of the leader, Curacron $500 \mathrm{EC}$, and 74 brands are listed with Paraquat as the active ingredient, with 35 of those products copying the name of Gramoxone 276 SL, the leading brand of herbicide. We presume that copycat companies only accentuate the visual aspects of the leading brand in designing product packaging and have no clear framework. We are interested in examining how to create an effective copycat by generating guidance related to the imitation of graphic elements of the leader's packaging: this is the first goal of the study.

Consumers purchase decisions in the crop-protection market are influenced by at least three actors in their reference group: farmer peers, agriculture kiosk owners and salespeople. Farmer peers are able to convince their friends based on their product-use experience, kiosk owners are able to convince farmers through their selling skills, and salespeople are able to convince farmers with their product knowledge. Copycats have a lower price tag and in the introduction phase, they usually persuade consumers by providing a free gift with purchase. Imagine the following situation: Pak Busar, a rice farmer, leaves for a nearby kiosk with the intent to buy Score $250 \mathrm{EC}$, a leading, trusted, quality-assured brand of Syngenta fungicide. When he arrives, kiosk owners recommend that he purchase Golskor $250 \mathrm{EC}$, a copycat brand with a much-lower price tag. Will Pak Busar make the purchase in line with his intention? Or will he decide otherwise? Will his evaluation change because Golskor 250 EC is recommended by others (i.e., farmer peers or salespeople)? Will it change because of the moderately lower price 
of Golskor 250 EC? Will it change if Golskor 250 EC is bundled with a free gift? Consumers experience many scenarios and it is possible that consumers' evaluation in a particular scenario will be different depending on the pesticide category; therefore, our experiments were developed to resemble this real market atmosphere as closely as possible.

This second objective is to understand which copycat referral, low-price strategy and sales-promotion strategy in each of three categories (insecticide, fungicide, and herbicide) receive the most positive evaluation by farmers. We also hope to test consumers' loyalty to the leading brand when confronted with copycats in certain situations (different copycat referrals, variations in the price differential between the copycat and the leading brand, different copycat sales promotions and different product categories). In this way, we can understand who wins the battle between leading brand and copycat, which is the third goal of our study.

Innovators and pioneers build and fund roads while imitators travel on it free, not only saving research and development costs and marketing efforts (saving $25-40 \%$ ) but also benefiting from consumers' previous knowledge of and experience using the innovator or pioneer's products and services (Shenkar, 2010). Davies (1998) argues that the fastest and easiest way for a brand to build an image is by stealing another brand's identity. Levitt (1966) even stresses that the most so-called new products actually imitate innovative products.

One important function of packaging is to stand out in a highly competitive marketplace (Sara, 1990; Silayoi and Speece, 2004; Rundh, 2005; Ogba and Johnson, 2010); however, copycats liken their trade dress to that of others. Packaging has the ability to communicate with the consumer (Robertson, 1990) at the critical point of their decision to make a purchase decision (Silayoi and Speece, 2007), instigating feelings and emotions (Lee, Gao and Brown, 2010). Copycats express and communicate through similar package design so that consumers experience equivalent feelings and emotions to those inspired by consumption of the market-leader brand. A copycat is a brand that imitates the trade dress of a leading product to take advantage of the leader's marketing image and reputation (Van Horen and Pieters, 2012a and 2012b). Because copycats seek to emulate the success of the original brand and are created with the intention to imitate, Zaichkowsky (1995) argues that a copycat can be completed using parts that belong to the original brand, including quality, performance, reliability, etc., and this generalization has a significant impact on consumers'behaviours and purchases. Copycat must be distinguished from counterfeits, which imitate the original product in its entirety (Kay, 1990). A copycatis designed to look like and make consumer think about the original product, whereas a counterfeit is an imitation of the original product, only with a cheaper price (d'Astous and Gargouri, 2001).

According to Van Horen and Pieters (2012b), copycats can be categorized into two groups: feature copycats and theme copycats. A feature copycat blatantly imitates the market leader's signature, thus quickly and directly activating consumer understanding and connection to the original, imitated brand. A theme copycat imitates the market leader's semantic or theme and is unlike a feature copycat in that a theme copycat is not directly connected to the market leader. A feature copycat is judged as more capable of taking advantage of its similarity to the market leader than is the theme copycat, which could be why this type of copycat becomes popular in the market.

Groups that can influence others' attitudes and behaviours - either directly or indirectly -are defined as a reference group (Kotler, 2003). Peter and Olson (2010) state that a reference group is one or more persons who that used as a reference point by others to develop the effective and cognitive responses that lead to behaviour, which has both a positive and a negative impact on consumers in that the preferred group will encourage consumers to affiliate and the non-preferred group will experience a contrasting result. A peer group tends to develop and share a particular meaning inside the group so that it can influence its members' purchase behaviour and consumption (Peter and Olson, 2010).

In various disciplines such as economics, psychology and marketing, the association between price and quality is extremely well understood and is often expressed as "the higher the price, the higher the quality." According to popular belief, consumers tend to use price as a sign of purchase decisions when they find that a product attribute is unclear (Tsao et al., 2005). Tsao et al. (2005) show that when a consumer makes a direct purchase, the association between price and quality is stronger than when a consumer obtains price information 
from an advertisement. Meanwhile, in their first study, DelVecchio and Puligadda (2012) find that lower price is related to lower product quality.

A free gift is one type of sales promotion that directly persuades the consumer to perform a purchase action (Peter and Olson, 2010). Huff, Alden and Tietje (1999) state that sales promotions-which are divided into monetary and non-monetary promotions -are designed to achieve short-term objectives. The presence of a sales promotion positively influences consumer purchase intention when the offered gift matches the product (Montaner, de Chernatony and Buil, 2011). According to Buil, de Chernatony and Martínez (2013), the impact of a sales promotion varies depending on the type of promotion. Monetary promotions have a negative influence on a product's perceived quality, whereas non-monetary promotions have a positive influence on both perceived quality and brand associations.

Companies copycat with the goal of their products becoming generalized with the leading brand (Zaichkowsky, 1995), having the ability to steal the other brand's identity (Davies, 1998), obtaining a free ride (Shenkar, 2010) and taking advantages of the benefits and reputation of the original product (Van Horen and Pieters, 2012b). One important prerequisite for effective copycatting to achieve its objectives is that the copycat must have similarity, connectedness and a relationship with the leader (Van Horen and Pieters, 2012b). When that relationship is achieved and brand identity has moved to the copycat, consumers evaluate both brands as having products of equal quality based on the similarity of their packaging (Loken, Ross and Hinkle, 1986).

In study 1 , we pretend to be a company that practices feature copycatting, with product quality as a property of the leading brand that is a target for theft. Through study 1 , we can generate copycat packaging design guidance; the advantage of that guidance is that it comes from real consumer (farmer) evaluations. This guidance will be used to develop a stimulus for study 2. Our study, which is related to copycat stimulus development, is different from those of previous researchers: d'Astous and Gargouri (2001) used existing copycats in the market as a stimulus, Warlop and Alba (2004) digitally develop a copycat stimulus but do not test it, and Miceli and Pieters (2010) create a copycat stimulus with the help of and following discussions with a professional graphic designers. Whereas Van Horen and Pieters (2012a and 2012b) generate a copycat stimulus based on general meaning described by student participants, their next study (2013) chooses an existing logo and packaging from the market as its copycat stimulus.

d'Astous and Gargouri (2001) and Van Horen and Pieters (2013) develop a copycat stimulus by taking a copycat product that already exists in the market. We assume that when using a product that is already on the market, the participant evaluation is not free from that product's influence. It is possible that the product has engaged in branding activity such as advertisements and below-the-line activity, either by the company or by participants who knew about the product either from friends or directly from participants who have experience consuming the product. Thus, one or both of the above conditions can influence participant evaluations. Miceli and Pieters (2010) and Van Horen and Pieters (2012a and 2012b) develop a copycat stimulus with a test based exclusively on general meaning (bad/good, unattractive/attractive, uninteresting/interesting, negative/positive), not from the copycat's ability to steal leader identity (our participants are asked about the closeness of the copycat stimulus to the quality of the leading brand's product). In terms of stimulus, we are certain that our study can contribute to enrich prior studies.

Kauppinen-Räisänen, Owusu and Bamfo (2012) note that packaging's impact on the consumer is contextual depending on the participant and the researched product. Accordingly, as stressed by Rettie and Brewer (2000), Rundh (2009) and Wang's (2013) packaging-related research, packaging should involve consumers. Silayoi and Speece (2007) are interested in the result of packaging research involving rural societies that work in the agricultural sector and involve Asian consumers.

We tried to alleviate prior researchers' concerns by designing a study with farmer involvement according to Gau, Jae and Viswanathan (2012), who include low-literate consumers, a group that often is unrepresented in the research. In terms of participants, our study is different than 6 prior studies of copycats (d'Astous and Gargouri, 
2001; Warlop and Alba, 2004; Miceli and Pieters, 2010; Van Horen and Pieters, 2012a, 2012b, 2013), all of which use student participants. According to Andersen et al. (2010) student homogeneity limits an experiment's ability to detect heterogeneity that exists in the wider population. Another aspect of our study that is different and novel is that reference group and sales promotions are two variables that to our knowledge have never been studied in the copycat literature.

\section{Conceptual Framework}

In a real market situation, it is quite possible for consumers to already have a purchase intention for the leading brand before they arrive at the agriculture kiosk because, according to Dick and Basu (1994), that intention is triggered by consumer brand loyalty. Repeat purchase intention occurs when consumers can accept the product, thus generating willingness to purchase again (and much more of it), as described by Schiffman and Kanuk (2004), who agree with Dick and Basu (1994) that all repeat purchase intention is related to brand loyalty. Romaniuk and Nenycz-Thiel (2013) claim that consumers' loyalty to certain brands results in strong brand associations between consumers and the brand. Dick and Basu (1994) state that consumer loyalty arises out of attitudes such as commitment, trust and satisfaction from belonging to a particular brand.

Become pioneers have been without rivals in the national crop-protection market for more than 30 years, multinational brands have established strong relationships with and attracted the loyalty of farmers. According to the National Pesticide Society (HMPN), multinational companies had a 60\% market share in 2012 (Antara, 2012). As pioneer brands, such companies have several advantages: a brand position with roots in consumer minds; high barriers to new brands with respect to product quality, advertisement and distribution; long-time domination of the market; the benefit of obstacles related to cost and experience that affect new brands; and advantages related to reputation and image (Haines, Chandran and Parkhe, 1989).

Since 2001, the market has changed drastically in terms of an increased number of brands: in 2013 there were 2705 brands listed, almost five times as many as in 2000, when there were only 594 brands (Indonesia Ministry of Agriculture, 2000 and 2013). Many of these additional brands are copycats, potentially influencing consumers' purchasing intention and behaviour because farmers now have many options related to products and price. According to Young, DeSarbo and Morwitz (1998), purchase intention cannot be generalized as an early sign of purchase behaviour: farmers who come to a kiosk with the intent to buy the leading brand could engage in the reverse behaviour. This study examined the impact of copycat presence (lower prices and sales promotions) on the purchase behaviour of leading brand-loyal consumers. We design our conceptual framework by stressing the advantages on the copycat side (recommended by all reference groups) and the leading brand that competes with the copycat. In terms of reference group recommendations, we focus on the influence of separate recommendations (farmer peers only or kiosk owners only or salespeople only), although in real life it is entirely possible that consumers could be influenced by more than one referral. Our study decided to input two degrees of copycats' lower price strategy: (1) moderately lower (15\% lower than leader brand); and (2) much lower (30\% lower than leader brand). For sales promotions, we focused on two situations: (1) copycats using a sales promotion of a free gift; and (2) copycats not using such a sales promotion. 
Figure 1. Conceptual framework

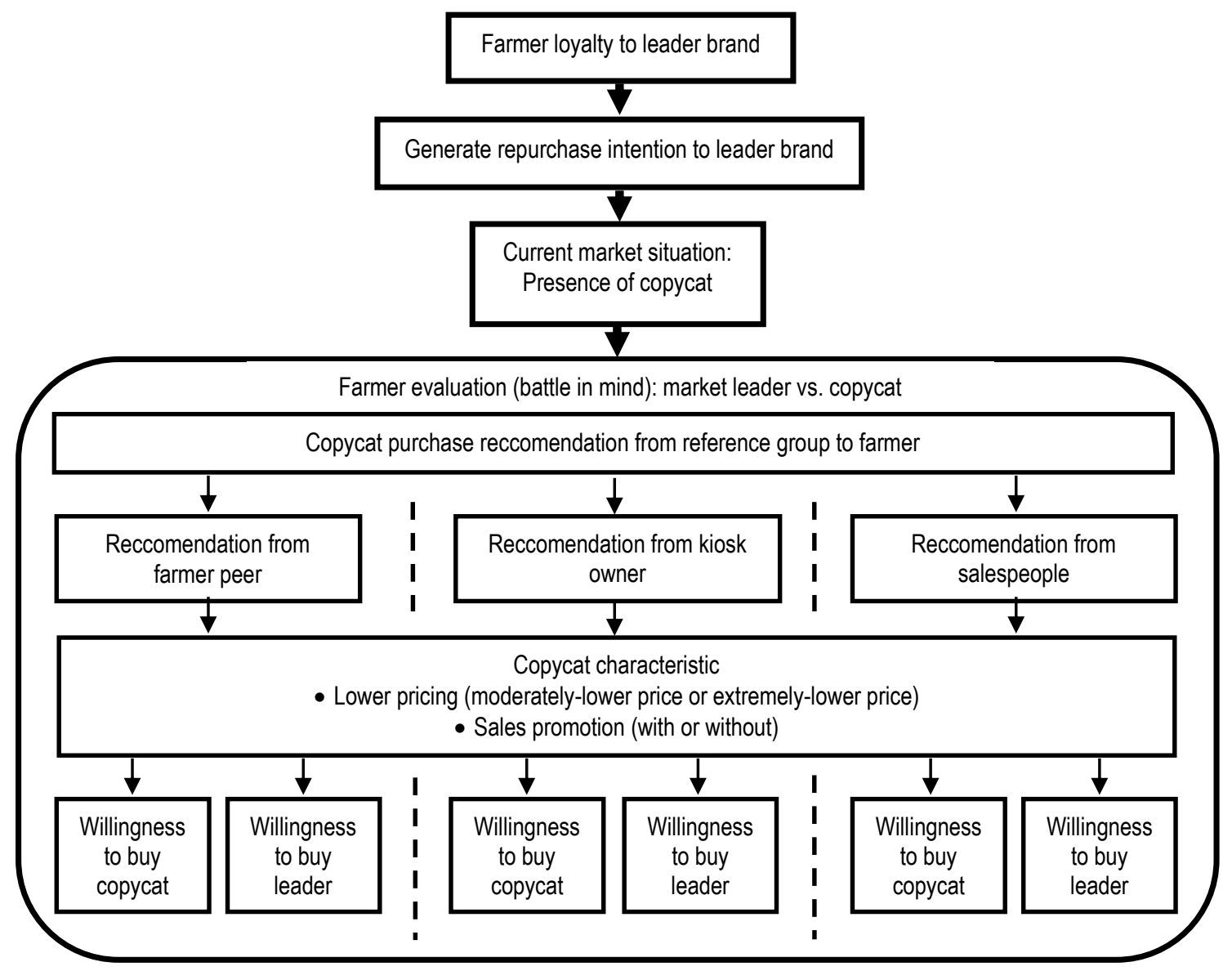

Method

The researchers chose to take an experimental approach so that we could observe behaviour and identify causality (Charness, Gneezy and Kuhn, 2012). Gau, Jae and Viswanathan (2012) suggest that this approach is appropriate for research among low-literate consumers. Based on the place of execution, Sekaran (2003) divided experimental design into two types: lab experiments and field experiments.

We decided to perform field experiments based on the following considerations:

1. The study area is far from our location, making it expensive to invite participants to a lab experiment.

2. Our participants are farmers whose cultivation activities vary; thus, we cannot be sure whether they will turn out for lab experiments in the number that we expect.

3. We want our participants to feel comfortable when they are participating in the experiment; the best, most comfortable places for them are the field, the agriculture kiosk and the house.

Involving low-literate consumers in our study was a challenge because we must devote attention to several issues, as stated by Gau, Jae and Viswanathan (2012). We eliminated reading and writing tasks by delivering our presentation using PowerPoint slides with audio (Study 1) and video (Study 2); all writing tasks are performed by an assistant; we simplified terms and used daily language (e.g.,the common word "obat" was employed in the presentation to mean "pesticide" whereas although its true meaning is "medicine"); we used visual scales for the evaluation task and we chose local people who can speak the local language as experiment assistants to make our participants comfortable, to encourage more to come and to prevent anxiety. 


\section{Study 1}

Product packaging has two important elements: visual and informational.Visual elements have the most influence on consumer product choice (Silayoi and Speece, 2004).

Figure 2. Product packaging elements (Silayoi and Speece, 2004)

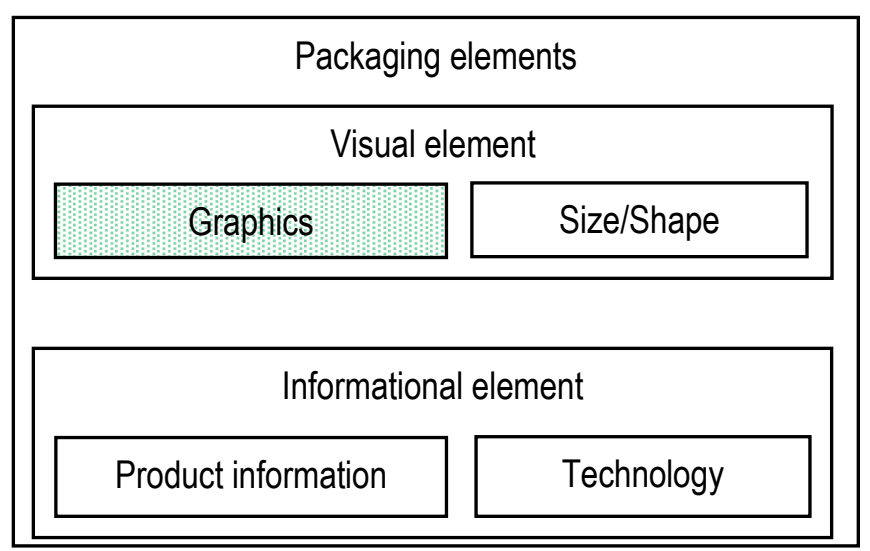

To develop packaging for a feature copycat, the study used graphics elements that consist of four elements: layout, colour, typography and photography (Silayoi and Speece, 2004).

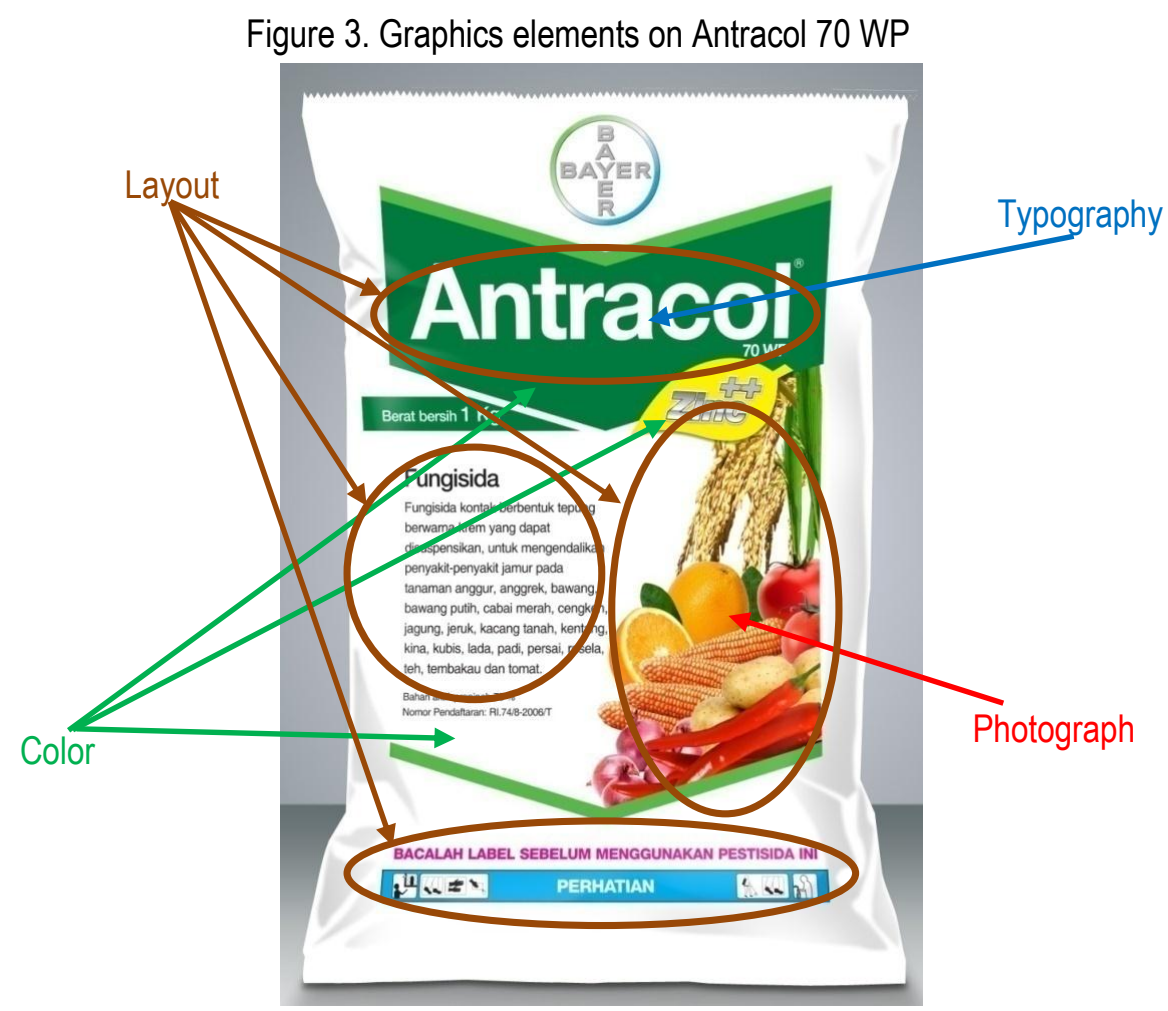

A copycat that imitates all of a competitor's graphical elements implicates legal issues such as case law on battery products involving brand GS against GiSi. The Supreme Court of Indonesia handed down a decision to cancel the GiSi brand, giving a win to leading brand GS, holding that GiSi has a similar name, layout and colour combination (Utami, 2015). Based on that consideration, we are sure that this strategy is unpopular because of the risk and thus, no copycat with imitation on four graphics elements is included in the study. Our decision is strengthened by Van Horen and Pieters (2012a), who state that blatant, high-similarity copycats are proven less threatening to leading brands than are moderate-similarity copycats. Moreover, imitation on one graphics element 
is also not included because we believe that imitation of a single element is inadequate to create a connection to the market leader.

From four elements, we are able to generate six combination of imitation on two graphics (A-F) and four combinations of imitation on three graphics (G-J).

Table 1. Imitation on 2 graphics

\begin{tabular}{|c|c|c|c|c|c|}
\hline \multicolumn{6}{|c|}{ Combination of graphics imitation } \\
\hline A & Typography & B & Typography & c & Typography \\
\hline A & Colour & B & Layout & $l$ & Photography \\
\hline & Colour & & Colour & F & Layout \\
\hline U & Layout & $E$ & Photography & $r$ & Photography \\
\hline
\end{tabular}

Table 2. Imitation on 3 graphics

\begin{tabular}{|c|c|c|c|c|c|c|c|}
\hline \multicolumn{8}{|c|}{ Combination of graphics imitation } \\
\hline & Typography & & Typography & & Colour & & Layout \\
\hline G & Colour & H & Colour & 1 & Layout & J & Photography \\
\hline & Layout & & Photography & & Photography & & Typography \\
\hline
\end{tabular}

We chose Antracol 70 WP, a leading, well-known fungicide brand of Bayer CropScience, as our copycatted product. A designer helped us create one picture that represented the leader brand and ten pictures that represented ten combinations of graphics imitations.

Study 1 applied a within-subject experiment with two steps of randomization: order of presentation and arrangement of participants. We conducted field experiments in the Probolinggo District of the Province of East Java because we consider that district's farmers to be very familiar with copycats. It is appropriate to ask users how to design copycat packaging. Two paid, trained college students performed two weeks of limited field experiments from 5 January 2015 to 18 January 2015. They visited field, kiosk and farmer residences in a search for willing participants. Once an experiment assistant procured a participant, the first step was to ask him/her to practice the experiments via trial presentation to ensure that he/she understood how to respond. The practice presentation was filled with pictures of foods and drinks; the farmers were asked to evaluate their taste on a sevenpoint scale with semantic differentials ("not delicious"/"very tasty"). Next, each participant's familiarity with the market leader was tested. Participants observed a picture of Antracol 70 WP for five seconds and evaluated it on three semantic differentials with seven point scales ("not familiar at all"/ "highly familiar", "never"/"often", "bad"/"good") adopted from Van Horen and Pieters (2012b). The final experiment asked farmers to evaluate ten copycat pictures (one at a time) on the equality of their efficacy and that of Antracol 70 WP on a single semantic differential on a seven-point scale ("not equal at all"/"highly equal"). The presentations were shown on a laptop and at the end we thanked farmers for their participation.

Ninety-eight farmers (70 men, $3340-50$ years of age, 58 of whom planted shallots) participated. We decided to use only data from participants who have $(M \geq 6)$ in the mean of the leading brand familiarity test that was used in our analysis. We argue only that the consumers who are very familiar with the leading brand $(M \geq 6)$ can provide valuable feedback with suitable and valuable input for copycat product development. There are 79 participants whose data can be calculated; the rest are eliminated. Descriptive statistics $(N=79)$ revealed that $A$ is the most positive evaluated picture $(M=5.67)$. The next sequence of the largest are $E(M=5.35), H(M=5.34), D(M=$ $5.29), I(M=5.29), \mathrm{G}(M=5.27), \mathrm{J}(M=5.06), \mathrm{B}(M=5.01), \mathrm{C}(M=5.01), \mathrm{F}(M=4.87)$. 
A

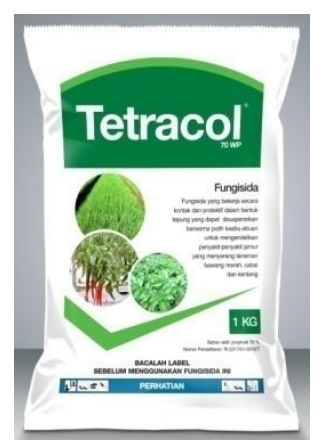

Imitation on

typography and colour

F

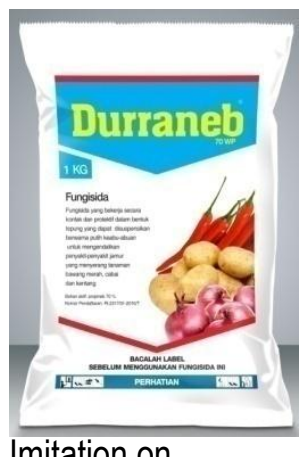

Imitation on

layout and photography
B

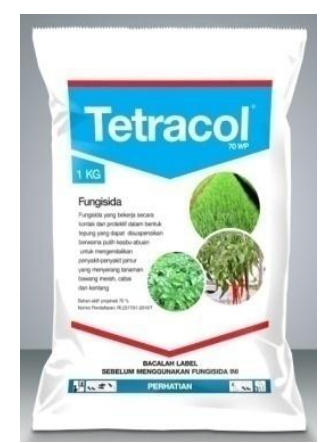

Imitation on

typography and

layout

G

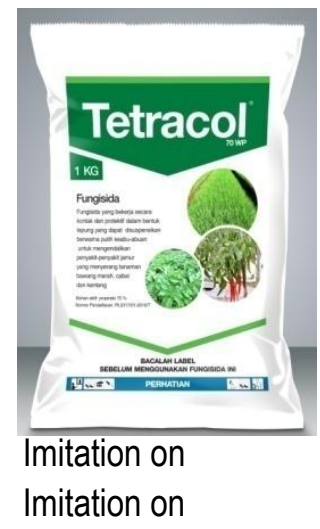

typography,

colour and

layout

Figure 4. Stimuli used in study 1

C

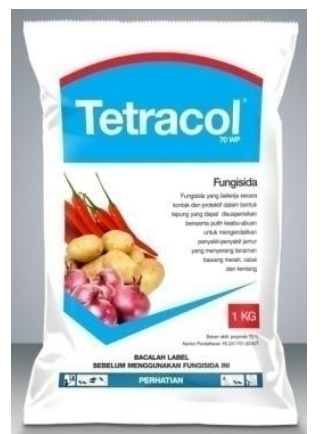

Imitation on

typography and

photography

H

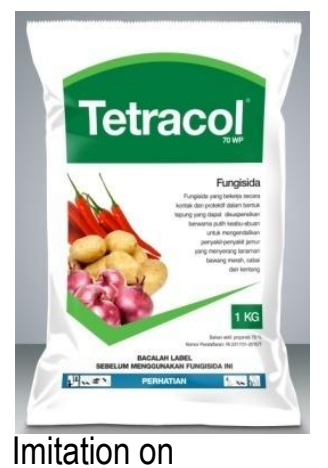

typography,

colour and

photography

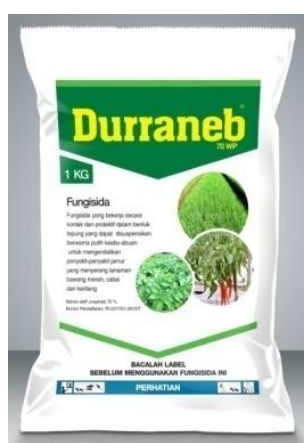

Imitation on

colour and

layout
E

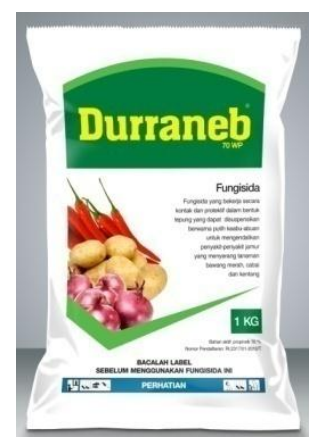

Imitation on

colour and

photography
।

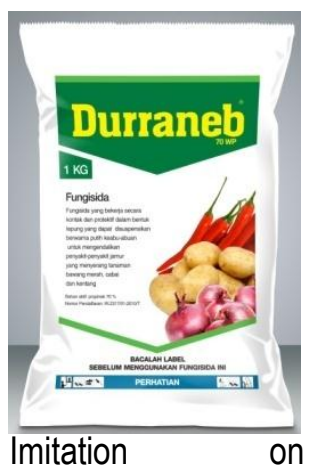

colour,

layout and

photography
$J$

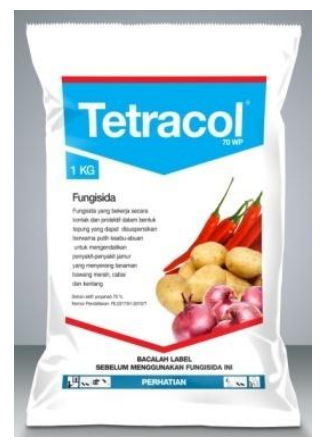

layout, photography \& typography

Study 1 proposed that imitating both typography and the colour of the leader's packaging is effective to steal the leader's quality image. The result shows that imitation of fewer graphics is the most positive, consistent with the research insights of d'Astous and Gargouri (2001) and Van Horen and Pieters (2012a). The first two researchers state that the excellence of an imitation had no impact on consumer evaluations of the copycat, whereas the latter two authors find that a moderate-similarity copycat can be more threatening than a high-similarity copycat. Colour is the only element that in the list of the top six (A-E-H-D-I-G) most positive consumer evaluations. Silayoi and Speece (2007) reveal that colour is the major influence in consumers' selection process. 
Figure 5. Mean of Copycat Packaging
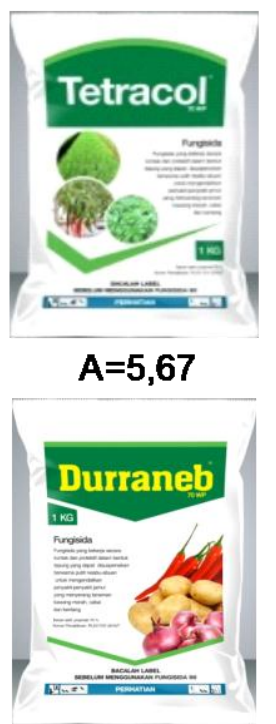

$I=5,29$

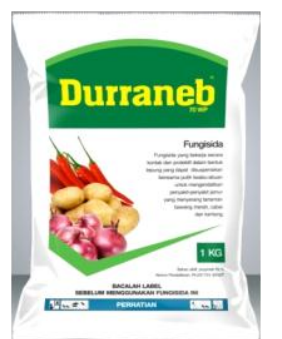

$E=5,35$

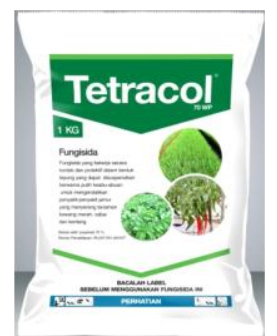

$\mathrm{G}=5,27$

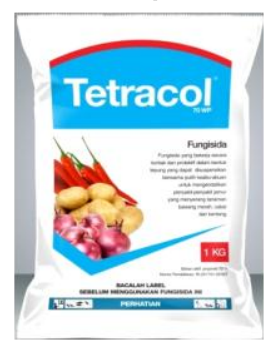

$\mathrm{C}=5,01$

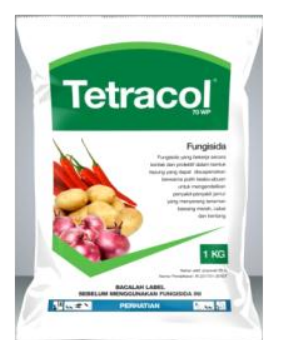

$H=5,34$

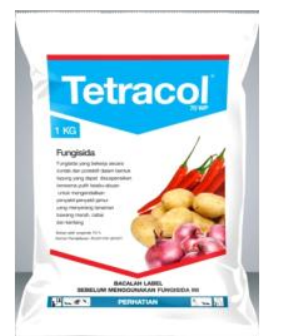

$\mathrm{J}=5,06$

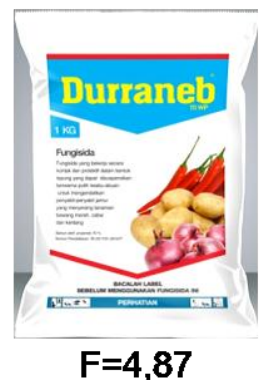

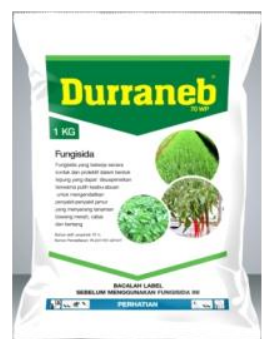

$D=5,29$

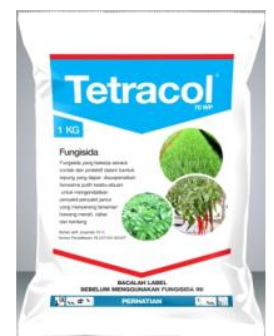

$B=5,01$

Study 2

Experiment Design and Stimuli Development

We randomly allocated participants to thirty-six situations in a between-subject experiment. The situation has a 3 (copycat referrals: farmer peers, kiosk owners, salespeople) $\times 2$ (copycat lower price: moderately lower, extremely lower) $\times 2$ (copycat sales promotions: with, without) $\times 3$ (product category: insecticide, fungicide, herbicide) design. Three districts in the province of East Java-Bojonegoro, Lumajang and Banyuwangi-were selected for Study 2 , representing the west side, centre and east side of the province. The study involved seventy-two participants from each district, meaning that two farmers per district were assigned to a single situation and thus, six participants overall were allocated to a single situation.

Table 3. Experiment design of study 2

\begin{tabular}{|c|c|c|c|c|c|c|}
\hline \multirow{2}{*}{$\begin{array}{l}3 \times 2 \times 2 \times 3 \\
\text { Factorial }\end{array}$} & \multicolumn{2}{|c|}{$\begin{array}{c}\text { Farmer peers } \\
\text { recommend copycat }\end{array}$} & \multicolumn{2}{|c|}{$\begin{array}{c}\text { Kiosk owners recommend } \\
\text { copycat }\end{array}$} & \multicolumn{2}{|c|}{ Salespeople recommend copycat } \\
\hline & $\begin{array}{l}\text { Moderately- } \\
\text { lower price }\end{array}$ & $\begin{array}{l}\text { Much lower } \\
\text { price }\end{array}$ & $\begin{array}{l}\text { Moderately- } \\
\text { lower price }\end{array}$ & $\begin{array}{l}\text { Much lower } \\
\text { price }\end{array}$ & $\begin{array}{l}\text { Moderately- } \\
\text { lower price }\end{array}$ & $\begin{array}{l}\text { Much lower } \\
\text { price }\end{array}$ \\
\hline Free gift & 1a-i & $1 b-\mathrm{i}$ & $2 a-i$ & $2 b-i$ & $3 a-i$ & $3 b-\mathrm{i}$ \\
\hline with & 1a-ii & $1 b-i i$ & 2a-ii & $2 b-i i$ & 3a-ii & $3 b-i i$ \\
\hline purchase & 1a-iii & 1b-iii & 2a-iii & $2 b-i i i$ & 3a-iii & $3 b-i i i$ \\
\hline No free gift & $1 c-i$ & $1 d-i$ & $2 c-i$ & $2 d-i$ & $3 c-i$ & $3 d-i$ \\
\hline with & 1c-ii & $1 d-i i$ & $2 c-i i$ & $2 d-i i$ & $3 c-i i$ & 3d-ii \\
\hline purchase & 1c-iii & 1d-iii & 2c-iii & 2d-iii & 3c-iii & 3d-iii \\
\hline
\end{tabular}


Remarks:

1st digit $\rightarrow$ Copycat referrals:

$1=$ Farmer peer

$2=$ Kiosk owners

$3=$ Salespeople

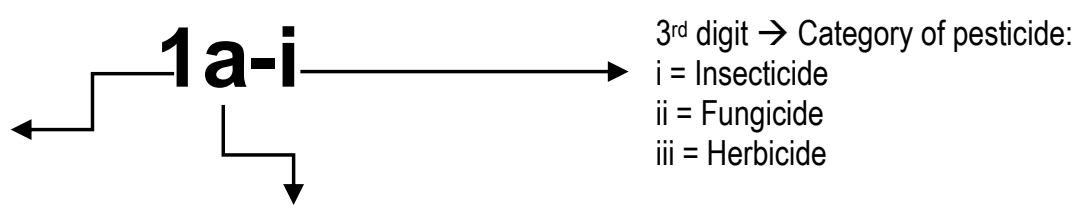

$2^{\text {nd }}$ digit $\rightarrow$ Copycat strategy:

$a=$ Moderately-lower price and with sales promotions

$b=$ Extremely-lower price and with sales promotions

$c=$ Moderately-lower price and without sales promotions

$d=$ Extremely-lower price and without sales promotions

One leading brand was picked for every category of pesticide i.e., Furadan 3 GR for insecticide, Score 250 EC for fungicide and Round Up 486 SL for herbicide. We developed copycat products by imitating the leaders' typography and colour as guidance generated by Study 1. To avoid trapping participants in the one-to-one comparison task and to create experiments that were as similar as possible to a market situation, we developed one no-copycat product for each category of pesticide. Graphic designers helped us produce the pictures and 36 videos were created to concretize situations 1a-i to 3d-iii (please see Table 3) for the participants.

Table 4. Stimuli used in Study 2

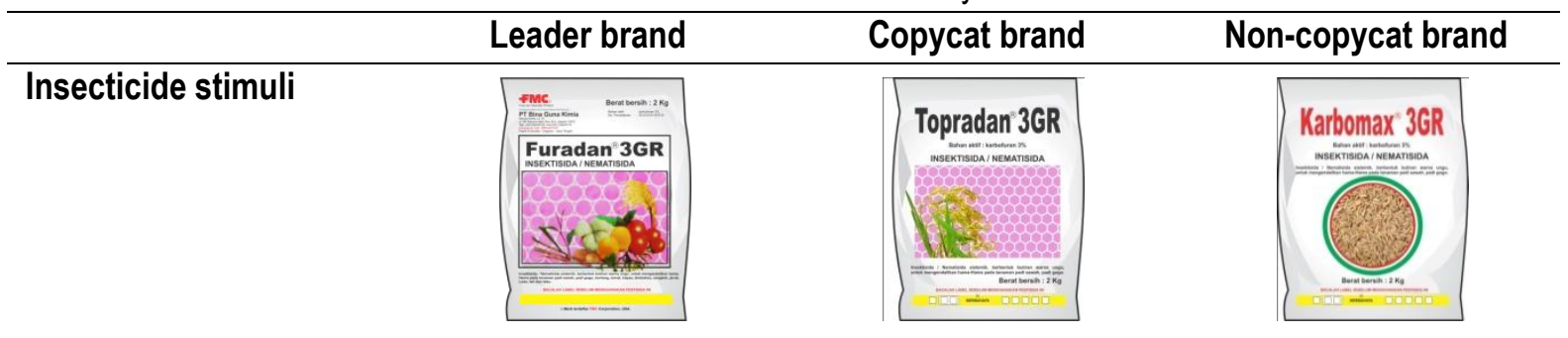

Fungicide stimuli


Table 5. Video summary of study 2

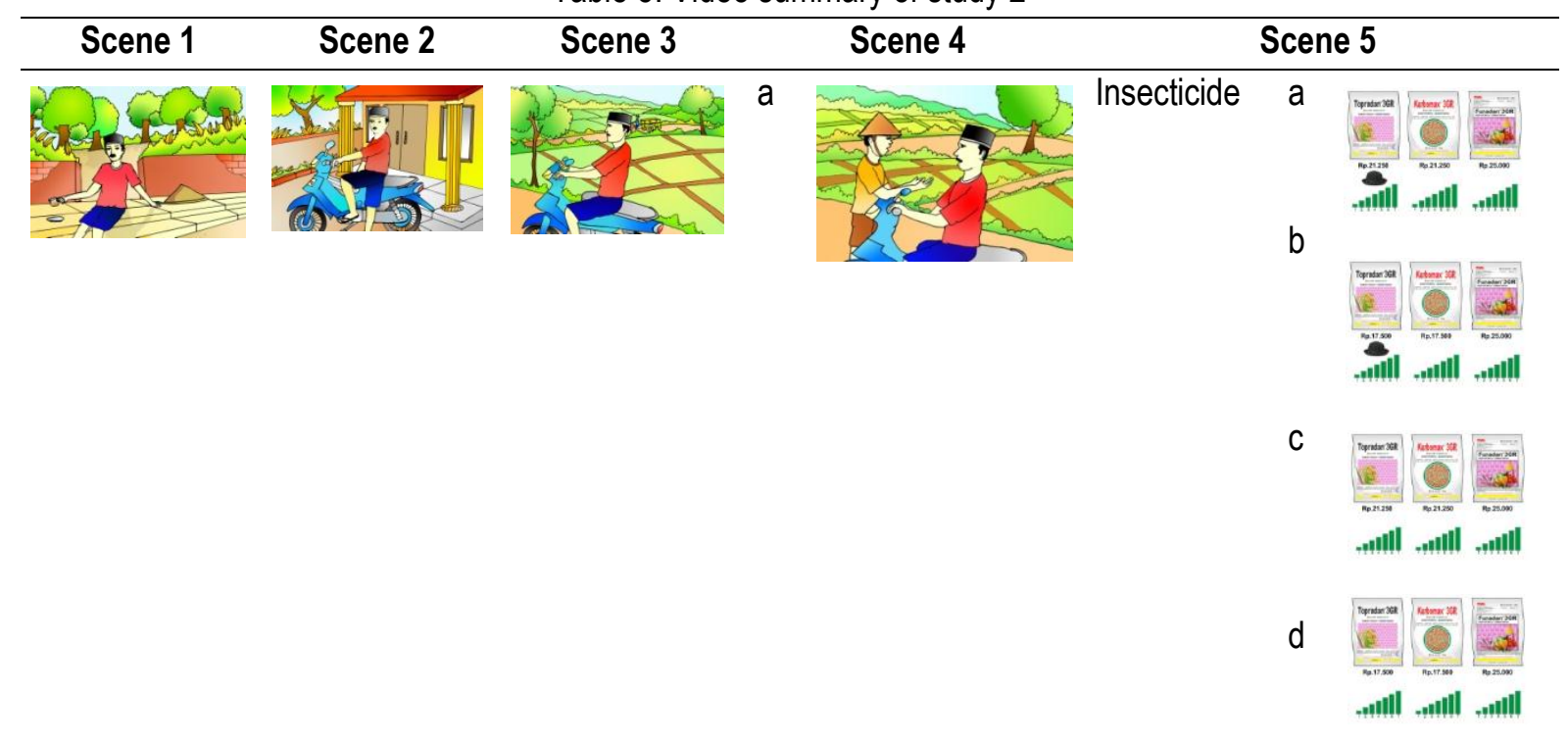

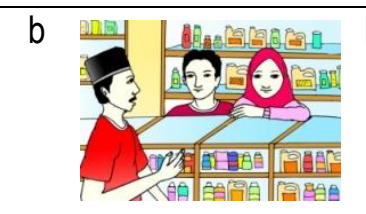

Fungicide a cle




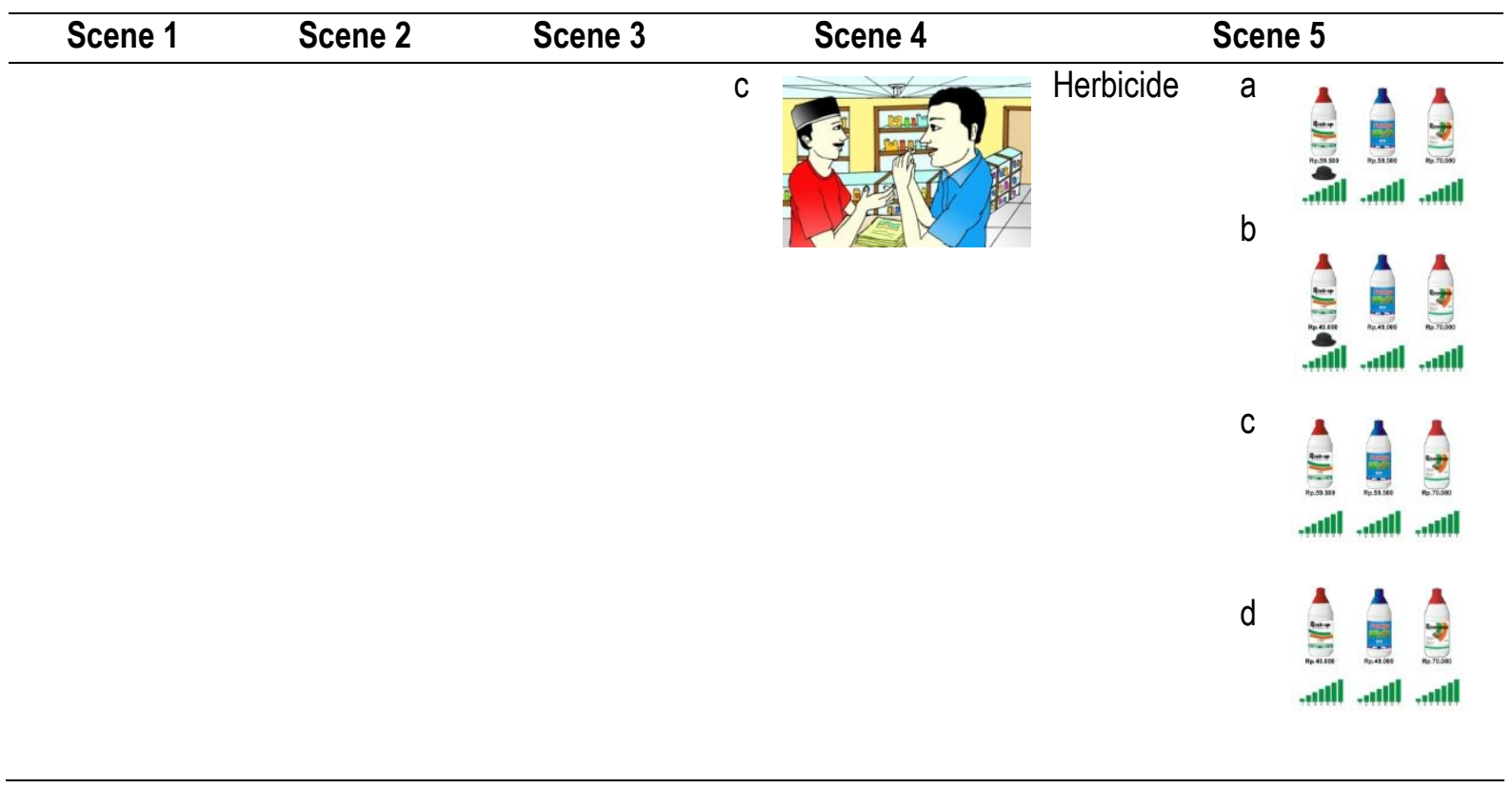

\section{Remarks}

Scene 1 : While resting after arriving from the field, participants were reminded to go to the kiosk to buy the leading brand (situations with $3^{\text {rd }}$ digit $\mathrm{i}=$ buy Furadan $3 \mathrm{GR}$; situations with $3^{\text {rd }}$ digit ii = buy Score $250 \mathrm{EC}$; situations with $3^{\text {rd }}$ digit iii = buy Round Up $486 \mathrm{SL}$ )

Scene 2 : Participants preparing to go to the nearby agriculture kiosk

Scene 3 : Participant on his way

Scene 4a: Farmer peers (situations with 1 st digit 1 ) recommend that participants buy a copycat brand 7 Situation (a/b/c/d)-i = buy Topradan $3 \mathrm{GR}$

Scene 4b: Kiosk owners (situations with 1 st digit 2) recommend that participants buy a copycat brand $\}$ Situation (a/b/c/d)-ii = buy Golskor $250 \mathrm{EC}$

Scene 4c: Salespeople (situations with 1st digit 3) recommend that participants buy a copycat brand $\int$ Situation (a/b/c/d)-iii = buy Rock Up 486 SL

Scene 5 : Participant evaluation (a: copycat at moderately-lower price with gift; b: copycat at much lower price with gift; c: copycat at moderately-lower price without gift; d: copycat at much lower price without gift)

\section{Procedure}

We employed six paid, trained experiment assistants in study 2. Three of them spent eleven days (21 May 2015 to 31 May 2015) finishing the field study in Bojonegoro. One assistant spent twenty-four days (6 May 2015 to 29 May 2015) researching participants in Lumajang. Two study helpers spent seven days (21 May 2015 to 27 May 2015) completing tasks in Banyuwangi. They looked for participants at farmers' favourite places, i.e., their residences, kiosks and fields. Participants were involved in three experiments-a practice session, a leading-brand familiarity test and a final experiment-that were presented on a laptop. The first experiment was designed to make farmers understand and become familiar with their tasks (using the practice presentation employed in study 1). The second experiment consisted of four leading brand-related questions: familiarity, usage, quality evaluation and purchase intention. A picture of the market leader was shown to the participants, who evaluated it on four semantic differentials using a seven-point scale ("not familiar at all"/"highly familiar", "never"/"often", "bad"/"good", "no"/"yes"). For the last task, participants were assigned to thirty-six situations and asked to evaluate their willingness to buy ("definitely no"/"definitely yes") three brands using a comparative screen with a seven-point scale. The indicators were adopted from Van Horen and Pieters (2012b).

\section{Hypotheses Development}

A peer group is a group of friends or associates with a similar background. Within the group, there is a tendency to develop and share certain meanings, thus influencing group members' purchase behaviour and consumption (Peter and Olson, 2010). We believe that farmers' peers have a positive impact on consumer evaluations. In the 
context of consumers' daily activity, kiosk owners are closer than salespeople because consumers consider the kiosk owners' recommendations second. Copycats will be evaluated positively by the reference groups sequence as follows: farmer peer $>$ kiosk owners $>$ salespeople. When farmer peers promote copycats, consumers will evaluate copycats most positively and the leading brand most negatively. Thus, the reference groups' influence on the evaluation of leading brands is seen in the following order: farmer peer < kiosk owners < salespeople. For these reasons, we arrive at the following hypotheses:

H1: (a) There will be a difference between consumers who receive a recommendation to buy a copycat from farmer peers (more positive) and consumers who receive a recommendation to buy a copycat from kiosk owners in terms of their willingness to buy a copycat.

(b) There will be a difference between consumers who receive a recommendation to buy a copycat from farmer peers (more negative) and consumers who receive a recommendation to buy a copycat from kiosk owners in terms of their willingness to buy a market leader.

(c) There will be a difference between consumers who receive a recommendation to buy a copycat from farmer peers (more positive) and consumers who receive a recommendation to buy a copycat from salespeople in terms of their willingness to buy a copycat.

(d) There will be a difference between consumers who receive a recommendation to buy a copycat from farmer peers (more negative) and consumers who receive a recommendation to buy a copycat from salespeople in terms of their willingness to buy a market leader.

(e) There will be a difference between consumers who receive a recommendation to buy a copycat from kiosk owners (more positive) and consumers who receive a recommendation to buy a copycat from salespeople in terms of their willingness to buy a copycat.

(f) There will be a difference between consumers who receive a recommendation to buy a copycat from kiosk owners (more negative) and consumers who receive a recommendation to buy a copycat from salespeople in terms of their willingness to buy a market leader.

Like Tsao et al. (2005) and DelVecchio and Puligadda's (2012) studies on price, our study finds that lower price is associated with lower product quality. Consumers will evaluate higher-priced copycats more positively than lower-priced ones, while making a contrary evaluation of the leading brand in the same situation. This provides the rationale for the following hypotheses.

H2: (a) There will be a difference between consumers who obtain a copycat at a moderately-lower price (more positive) and consumers who obtain a copycat at a much lower price in terms of their willingness to buy a copycat.

(b) There will be a difference between consumers who obtain a copycat at a moderately-lower price (more negative) and consumers who obtain a copycat at a much lower price in terms of their willingness to buy a market leader.

Non-monetary promotions such as free gifts have a more positive impact on perceived quality than do monetary promotions (Buil, de Chernatony and Martínez, 2013). A hat is an attractive gift in the crop-protection market: as noted by Buil, de Chernatony and Montaner (2013), such a gift can significantly drive consumer evaluation. We predicted that consumers will be more willing to buy a copycat that comes with a free hat than a copycat that comes without a gift. In the same situation involving a leading brand, we conclude the reverse. These findings are the basis of our third hypotheses.

H3: (a) There will be a difference between consumers who receive a copycat with a free gift (more positive) and consumers who receive a copycat without a free gift in terms of their willingness to buy a copycat. 
(b) There will be a difference between consumers who receive a copycat with a free gift (more negative) and consumers who receive a copycat without a free gift in terms of their willingness to buy a market leader.

\section{$\underline{\text { Result }}$}

In Bojonegoro, seventy-two farmers (58 men, 31 aged 50-60 years, 58 rice farmers) participated in our research. The district of Lumajang was represented by seventy-two farmers (72 men, 30 aged 40-50 years, 54 rice farmers) and the district of Banyuwangi was represented by seventy-two farmers (70 men, 42 aged 40-50 years, 57 rice farmers). Overall, 216 farmers (200 men, 90 aged 40-50 years, 169 rice farmers) participated.

We dismissed forty-two responses from participants with a purchase intention of less than four for the leading brand because the study stressed finding the impact of a copycat's presence on leader-loyal consumers. A factorial ANOVA was employed to test a 3 (copycat referrals $=R$ ) $\times 2$ (copycat lower price $=P$ ) $\times 2$ (copycat sales promotions $=\mathrm{G}) \times 3$ (product category $=\mathrm{C}$ ) between-subject design.

Table 6. Tests of Between-Subjects Effects

Dependent variable: Consumers' willingness to buy a copycat

\begin{tabular}{lrrrrr}
\hline Source & $\begin{array}{c}\text { Type III Sum of } \\
\text { Squares }\end{array}$ & \multicolumn{1}{c}{ Df } & Mean Square & \multicolumn{1}{l}{ F } & \multicolumn{1}{l}{ Sig. } \\
\hline Corrected Model & $134.629 \mathrm{a}$ & 32 & 4.207 & .843 & .707 \\
Intercept & 2232.034 & 1 & 2232.034 & 447.423 & .000 \\
$\mathrm{R}$ & 12.660 & 2 & 6.330 & 1.269 & .284 \\
$\mathrm{P}$ & 1.273 & 1 & 1.273 & .255 & .614 \\
$\mathrm{G}$ & .401 & 1 & .401 & .080 & .777 \\
$\mathrm{C}$ & 23.796 & 2 & 11.898 & 2.385 & .096 \\
$\mathrm{R}^{*} \mathrm{P}$ & 2.607 & 2 & 1.303 & .261 & .770 \\
$\mathrm{R}^{*} \mathrm{G}$ & 4.239 & 2 & 2.119 & .425 & .655 \\
$\mathrm{R}^{*} \mathrm{C}$ & 25.335 & 4 & 6.334 & 1.270 & .285 \\
$\mathrm{P}^{*} \mathrm{G}$ & .250 & 1 & .250 & .050 & .823 \\
$\mathrm{P}^{*} \mathrm{C}$ & 2.092 & 2 & 1.046 & .210 & .811 \\
$\mathrm{G}{ }^{*} \mathrm{C}$ & 2.626 & 2 & 1.313 & .263 & .769 \\
$\mathrm{R}^{*} \mathrm{P}{ }^{*} \mathrm{G}$ & .875 & 1 & .875 & .175 & .676 \\
$\mathrm{R}^{*} \mathrm{P}{ }^{*} \mathrm{C}$ & 15.401 & 4 & 3.850 & .772 & .545 \\
$\mathrm{R}^{*} \mathrm{G}{ }^{*} \mathrm{C}$ & 24.420 & 4 & 6.105 & 1.224 & .303 \\
$\mathrm{P}^{*} \mathrm{G}{ }^{*} \mathrm{C}$ & 6.709 & 2 & 3.355 & .672 & .512 \\
$\mathrm{R}^{*} \mathrm{P}{ }^{*} \mathrm{G}$ & 12.805 & 2 & 6.403 & 1.283 & .280 \\
Error & 703.399 & 141 & 4.989 & & \\
Total & 3519.000 & 174 & & & \\
Corrected Total & 838.029 & 173 & & & \\
\hline
\end{tabular}

a. $R$ Squared $=, 161$ (Adjusted R Squared $=-, 030$ )

As shown in Table 6, copycat referrals $(F(2,141)=1.269, p>.05)$, copycat lower price $(F(1,141)=.255, p$ $>.05)$, copycat sales promotions $(F(1,141)=.080, p>.05)$ and product category $(F(2,141)=2.385, p>.05)$ did not have a significantly different impact on consumers'willingness to buy a copycat. Interaction effects of the independent variables were also absent, as shown by all $p>.05$. 
Table 7. Tests of Between-Subjects Effects

Dependent variable: Consumers' willingness to buy a market leader

\begin{tabular}{lrrrrr}
\hline Source & $\begin{array}{c}\text { Type III Sum of } \\
\text { Squares }\end{array}$ & \multicolumn{1}{c}{ Df } & Mean Square & \multicolumn{1}{c}{ F } & Sig. \\
\hline Corrected Model & $49.043^{\mathrm{a}}$ & 32 & 1.533 & .600 & .953 \\
Intercept & 5151.279 & 1 & 5151.279 & 2017.859 & .000 \\
$\mathrm{R}$ & 3.483 & 2 & 1.742 & .682 & .507 \\
$\mathrm{P}$ & 3.890 & 1 & 3.890 & 1.524 & .219 \\
$\mathrm{G}$ & .958 & 1 & .958 & .375 & .541 \\
$\mathrm{C}$ & 2.386 & 2 & 1.193 & .467 & .628 \\
$\mathrm{R}^{*} \mathrm{P}$ & 4.427 & 2 & 2.213 & .867 & .422 \\
$\mathrm{R}^{*} \mathrm{G}$ & 2.151 & 2 & 1.075 & .421 & .657 \\
$\mathrm{R}^{*} \mathrm{C}$ & 8.872 & 4 & 2.218 & .869 & .484 \\
$\mathrm{P}^{*} \mathrm{G}$ & .445 & 1 & .445 & .174 & .677 \\
$\mathrm{P}^{*} \mathrm{C}$ & 2.522 & 2 & 1.261 & .494 & .611 \\
$\mathrm{G}^{*} \mathrm{C}$ & 3.627 & 2 & 1.814 & .710 & .493 \\
$\mathrm{R}^{*} \mathrm{P}{ }^{*} \mathrm{G}$ & 3.554 & 1 & 3.554 & 1.392 & .240 \\
$\mathrm{R}^{*} \mathrm{P}{ }^{*} \mathrm{C}$ & 4.910 & 4 & 1.228 & .481 & .750 \\
$\mathrm{R}^{*} \mathrm{G}{ }^{*} \mathrm{C}$ & 4.869 & 4 & 1.217 & .477 & .753 \\
$\mathrm{P}^{*} \mathrm{G}{ }^{*} \mathrm{C}$ & 2.369 & 2 & 1.184 & .464 & .630 \\
$\mathrm{R}^{*} \mathrm{P}{ }^{*} \mathrm{G}{ }^{*} \mathrm{C}$ & 2.190 & 2 & 1.095 & .429 & .652 \\
Error & 359.951 & 141 & 2.553 & & \\
Total & 6661.000 & 174 & & & \\
Corrected Total & 408.994 & 173 & & & \\
\hline
\end{tabular}

a. $R$ Squared $=, 120$ (Adjusted R Squared $=-, 080$ )

As shown in Table 7, copycat referrals $(F(2,141)=.682, p>.05)$, lower prices for copycats $(F(1,141)$ $=1.524, p>.05)$, copycat sales promotions $(F(1,141)=.375, p>.05)$ and product category $(F(2,141)=.467, p>$ $.05)$ did not have a significantly different impact on consumers' willingness to buy the leading brand. The interaction effects of the independent variables that were not present were shown by all $p>.05$.

\section{Hypotheses Testing and Findings}

Although the results did not find that the independent variables had a significant effect on consumers' willingness to buy a copycat versus the market leader in a comparative situation, we consider it essential to highlight our important findings. We start with the following hypotheses:

H1: (a) Consumer willingness to buy a copycat is more positive when farmer peers recommend the copycat $(M=4.28, S D=2.41)$ than when kiosk owners recommend the copycat $(M=3.55, S D=2.10) \rightarrow$ Supported.

(b) Consumer willingness to buy a market leader is more negative when farmer peers recommend the copycat $(M=5.84, S D=1.73)$ than when kiosk owners recommend the copycat $(M=6.02, S D=$ 1.54) $\rightarrow$ Supported.

(c) Consumer willingness to buy a copycat is more positive when farmer peers recommend the copycat $(M=4.28, S D=2.41)$ than when salespeople recommend the copycat $(M=3.95, S D=2.06) \rightarrow$ Supported.

(d) Consumer willingness to buy a market leader is more negative when farmer peers recommend the copycat $(M=5.84, S D=1.73)$ than when salespeople recommend the copycat $(M=6.12, S D=$ 1.34) $\rightarrow$ Supported. 
(e) Consumer willingness to buy a copycat is more positive when kiosk owners recommend the copycat $(M=3.55, S D=2.10)$ than when salespeople $(M=3.95, S D=2.06)$ recommend the copycat $\rightarrow$ Not supported.

(f) Consumer willingness to buy a market leader is more negative when kiosk owners recommend the copycat $(M=6.02, S D=1.54)$ than when salespeople recommend the copycat $(M=6.12, S D=$ 1.34) $\rightarrow$ Supported.

H2: (a) Consumer willingness to buy a copycat is more positive when the copycat is offered at a moderatelylower price $(M=3.99, S D=2.27)$ than when the copycat is offered at a much lower price $(M=3.87$, $\mathrm{SD}=2.14) \rightarrow$ Supported.

(b) Consumer willingness to buy the market leader is more negative when the copycat is offered at moderately-lower price $(M=5.91, S D=1.73)$ than when the copycat is offered at a much lower price $(M=6.08, S D=1.33) \rightarrow$ Supported.

H3: (a) Consumer willingness to buy a copycat is more positive when the copycat is accompanied by a free gift $(M=3.74, S D=2.15)$ than when the copycat is not accompanied by a free gift $(M=4.11, S D=$ 2.25) $\rightarrow$ Not supported.

(b) Consumer willingness to buy a market leader is more negative when the copycat is accompanied by a free gift $(M=6.09, S D=1.25)$ than when the copycat is not accompanied by a free gift $(M=5.90$, $\mathrm{SD}=1.78) \rightarrow$ Not supported.

Our research succeeded in finding the most favourable conditions for copycats, which will be achieved when copycats exploit farmers as referrals, use moderately-lower price strategies and decline to use sales promotions. We can break down the ideal copycat situation by category of pesticide as shown in Figure 6 . The most favourable conditions for insecticide copycats occurred when farmers were appointed to promote copycats, when copycats' prices were set at a moderately-lower level than the leader and when copycats were sold without a free gift. The same advantageous situation will exist for copycat fungicides when they go to market following the exact steps taken by insecticides, except that brand referrals should be made by salespeople. Copycat herbicides will experience the most propitious situation if farmers are designated as brand ambassadors, if a strategy of much lower prices is employed and if a free-gift-with-purchase program is employed.

Figure 6. Favourable situations for copycats Insecticide

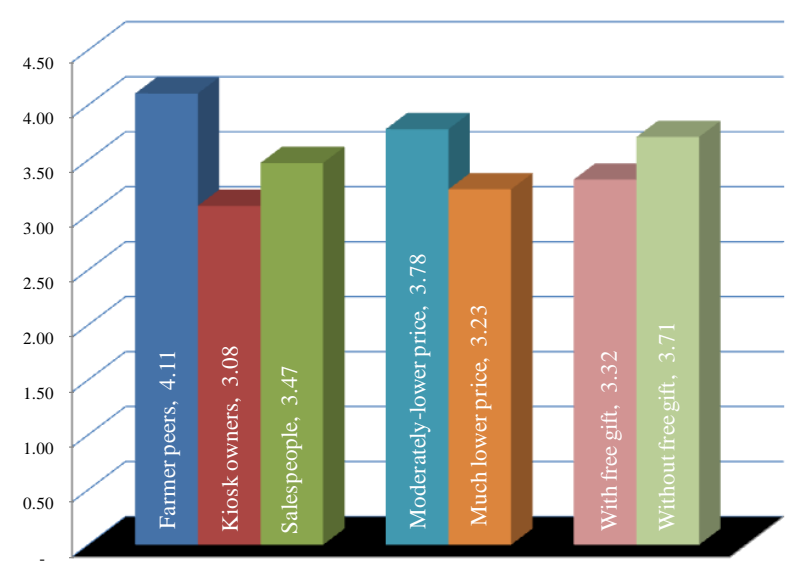


Fungicide

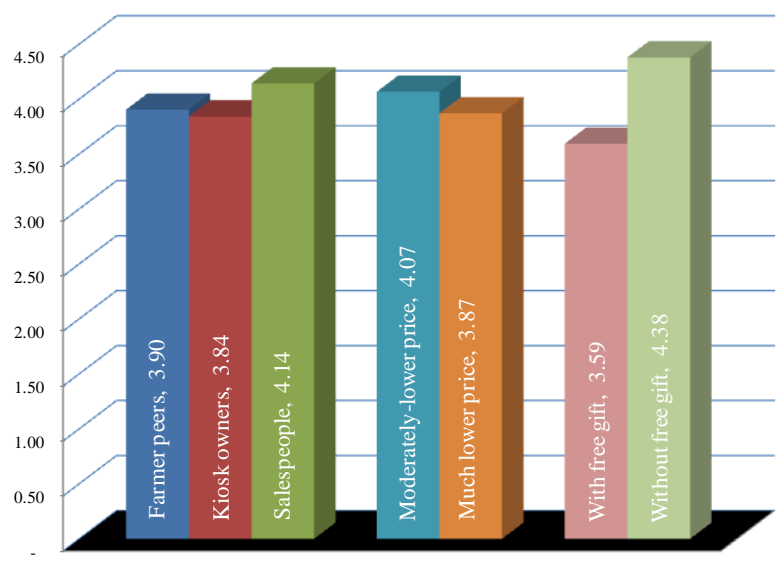

Herbicide

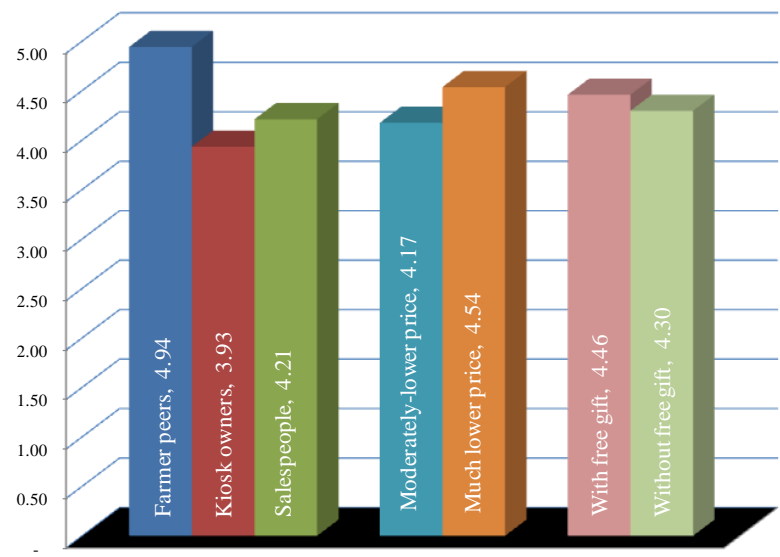

This study finally determined whether the heavily armed copycat or the market leader won the market battle. In every field, as featured in Figures 7, we see the leading brand overcome the copycat's aggression.

Figure 7. Copycat versus Market Leader on Reference Group Recommendation

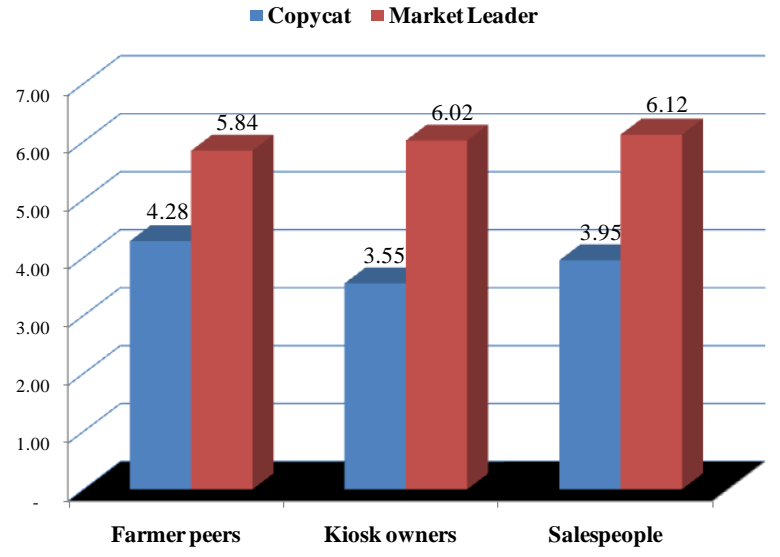

on Pricing Strategy

- Copycat $\square$ Market Leader

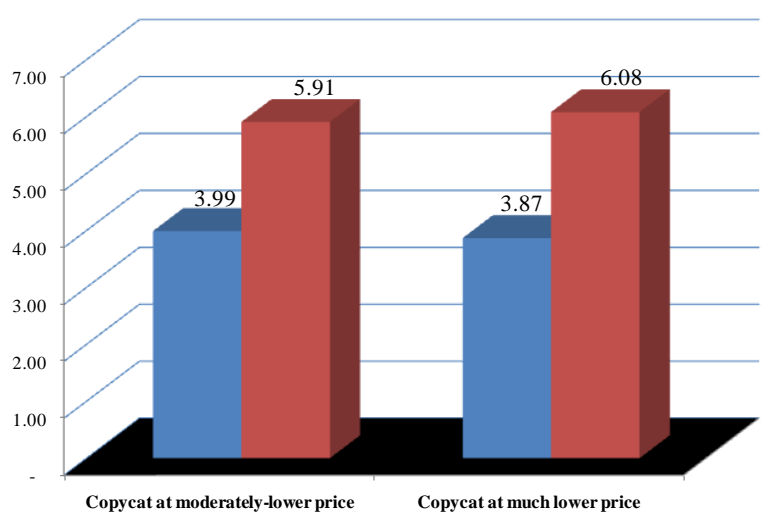

on Sales Promotion Strategy

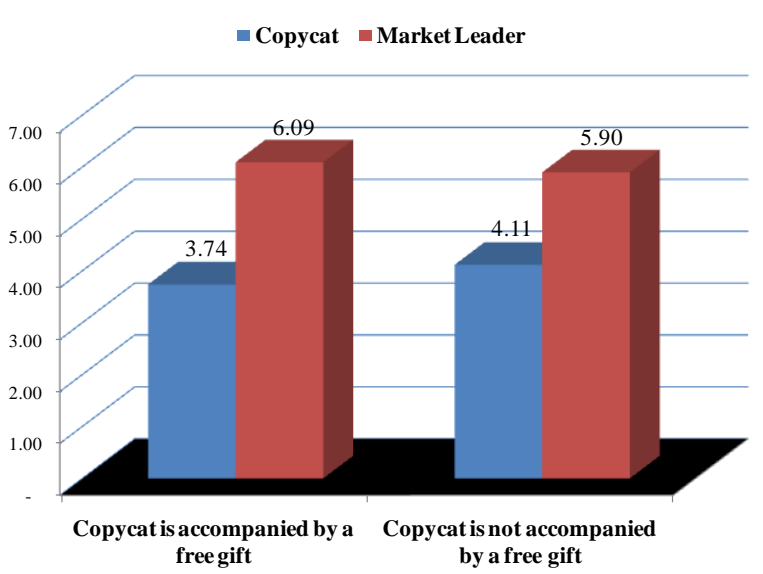

One interesting finding is that because the copycat receives the most positive evaluation, the leading brand receives the most negative evaluation in the same situation. Copycats are evaluated most positively $(M=4.28)$ 
when recommended by farmer peers; in the same situation, consumers evaluated the leader brand most negatively $(M=5.84)$. When copycats were offered at a moderately-lower price, consumers gave it the highest evaluation $(M=3.99)$ while giving the leading brand the lowest evaluation $(M=5.91)$. Copycats without sales promotion receive the most positive consumer evaluation $(M=4.11)$, whereas in the same situation the leading brand received the most negative consumer evaluation $(M=5.90)$.

Figure 8. Copycat versus Market Leader by Pesticide Category

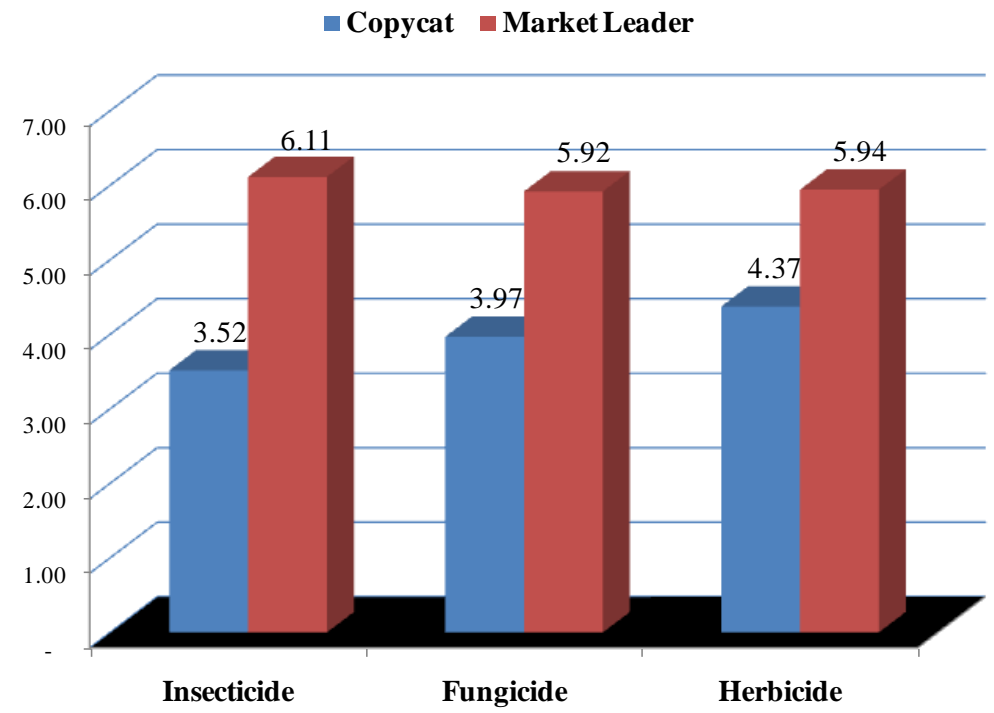

Figure 8 shows that in the herbicide category, copycats are more accepted $(M=4.37)$ by consumers than in the fungicide $(M=3.97)$ and insecticide $(M=3.52)$ categories. We also can see that the leading brand is the most resistance to copycat attack in the insecticide $(M=6.11)$ category.

\section{Discussion}

Imitation is common in the business world and is applied in various forms. Some parties characterize it as foul, counter-creative and hurting innovators, whereas dissenters argues that mimicry is not as despicable as alleged because it requires a great deal of effort to create a perfect-likeness copycat. The phenomenon of emerging markets may encourage manufacturers to step on the innovation pedal to generate new products that satisfy diverse market segments. When creativity cannot counterbalance the speed of product demand, imitation may overtake it.

Study 1 argues that copycats might be able to compete by imitating less of the leading brand's competitive skills, although as shown in Study 2, copycats failed to strike innovators. However, as pioneer brands for more than three decades, market leaders possessed many advantages, and our results are reasonable. Understanding favourable situations is important for copycats because that understanding helps in developing effective and efficient marketing tactics. By directing marketing efforts appropriately to the targeted consumer in positive situations, copycats become effective. By reducing the investment cost in trial-and-error attempts to identify favourable situations, copycats become efficient. The winner learns additional lessons by emulating copycatadvantageous situations and considering those situations when formulating marketing intelligence. This study provides insights into both brands so that they can continue to focus on future competition in the field of crop protection.

\section{Study limitations and future research}

This study has limitations related to implementing experiments. We found that laptop usage is less practical and presents battery-life issues. In the future, tablets should be optional. Typography and colour on Study 1 were 
determined by designer without pre-test. There were no pre-test presentations of Studies 1 and 2 to ensure that their content would be understandable to the targeted participants. This issue is rendered less serious by the experiment assistants' ability to speak the local language. The video used in Study 2 displayed male farmers despite the fact that some of the participants were female. Moreover, three of the products displayed in the evaluation scene were not randomly presented. Various experiment locations (residences, field, and kiosk) may result in differences in participants' responses caused by comfort, fatigue and time-availability issues. It was difficult to create isolated field experiments because participants' family and friends were often curious about the process. We established the "moderately-lower" copycat price as $15 \%$ less and the "much lower" copycat price as $30 \%$ less based on our assumptions.

To certify our study, future researchers can conduct the following experiments: investigate consumers' age and/or the homogeneity of their crops. Younger farmers may have a different response to copycats. Similarly, a group of vegetable farmers might potentially evaluate copycat brands than farmers who plant fruit or rice. We concluded that the feature copycat is unable to counter the market leader. Van Horen and Pieters (2012b) have proven that the feature-copycat approach is less effective than the theme-copycat approach. It would be interesting to inspect how leading brand defends against theme copycats. It would be readable to examine copycatting from the consumer-appropriateness perspective and from the corporate side (product manager, sales manager) perspective. Future researchers can particularize copycatting in the hospitality industry in which involves services instead of physical products and our experimental framework can duplicated in research on other industries.

\section{References}

Andersen, S., Harrison, G.W., Lau, M.I. and Rutström, E.E. (2010), "Preference heterogeneity in experiments: comparing the field and laboratory", Journal of Economic Behavior \& Organization, Vol. 73, pp. 209-224

Antara, 2012. 'Pasar Pestisida Nasional Masih Dikuasai Industri Multinasional', Antara, 20 March. Available from http://id.berita.yahoo.com/pasar-pestisida-nasional-masih-dikuasai-industri-multinasional165632175.html [Accessed 27 November 2013]

Buil, I., de Chernatony, L. and Martínez, E. (2013). "Examining the role of advertising and sales promotions in brand equity creation", Journal of Business Research, Vol. 66, pp. 115-122.

Buil, I., de Chernatony, L. and Montaner, T. (2013). "Factors influencing consumer evaluations of gift promotions", European Journal of Marketing, Vol. 47, No.3/4 pp. 574-595.

Charness, G., Gneezy, U. and Kuhn, M.A. (2012). "Experimental methods: Between-subject and within-subject design", Journal of Economic Behavior \& Organization, Vol. 81, pp. 1-8.

Davies, G. (1998). "Retail brands and the theft of identity", International Journal of Retail \& Distribution Management. Vol. 26 No.4, pp. 140-146.

DelVecchio, D. and Puligada, S. (2012), "The effects of lower prices on perceptions of brand quality: a choice task perspective", Journal of Product \& Brand Management, Vol. 21 No.6, pp. 465-474.

Department of Agriculture, Directorate-General of Agriculture Infrastructure (2013) Agriculture and Forestry Pesticide 2011. Bina Sarana Pertanian Cooperative

Department of Agriculture, Secretariat-General (2000) Agriculture and Forestry Pesticide 2000. Employee Cooperative of Department of Agriculture

Dick, A.S. and Basu, K. (1994), "Customer loyalty: Toward an integrated conceptual framework", Journal of the Academy of Marketing Science, Vol. 22 No. 2, pp. 99-113.

d'Astous, A. and Gargouri, E. (2001), "Consumer evaluations of brand imitations", European Journal of Marketing, Vol. 35 No. 1/2, pp. 153-167.

Gau, R., Jae, H. and Viswanathan, M. (2012), "Studying low-literate consumers through experimental methods: Implications for subsistence marketplaces”, Journal of Business Research, Vol. 65, pp. 1683-1691. 
Haines, D. W., Chandran, R. and Parkhe, A. (1989), "Winning by being the first to market... or second?", The Journal of Consumer Marketing, Vol. 6 No.1, pp. 63-69.

Huff, L.C., Alden, D.L. and Tietje, B.C. (1999), "Managing the sales promotion mix: brand managers' response to sales promotions", Journal of Promotion Management, Vol. 5 No. 1, pp. 77-89.

Kauppinen-Räisänen, H., Owusu, R.A. and Bamfo, B.A. (2012), "Brand salience of OTC pharmaceuticals through package appearance", International Journal of Pharmaceutical and Healthcare Marketing, Vol. 6 No. 3, pp. 230-249.

Kay, H. (1990), "Fake's progress", Management Today, July, pp. 54-8.

Kotler, P. (2003), Marketing Management. 11th ed. New Jersey: Pearson Education, Prentice-Hall, Upper Saddle River.

Lee, J.Y., Gao, Z. and Brown, M.G. (2010), "A study of the impact of package changes on orange juice demand", Journal of Retailing and Consumer Service, Vol. 17 pp. 487-491.

Levitt, T. (1966), "Innovative imitation", Harvard Business Review, September-October, pp. 63-70

Loken, B., Ross, I., and Hinkle, R.L. (1986), "Consumer "confusion" of origin and brand similiarity perceptions", Journal of Public Policy and Marketing, Vol. 5 pp. 195-211

Miceli, G.N. and Pieters, R. (2010), "Looking more or less alike: Determinants of perceived visual similarity between copycat and leading brands", Journal of Business Research, Vol. 63 pp. 1121-1128.

Montaner, T., de Chernatony, L. and Buil, I. (2011), "Consumer response to gift promotions", Journal of Product and Brand Management, Vol. 20 No. 2, pp 101-110.

Ogba, I.E. and Johnson, R. (2010), "How packaging affects the product preferences of children and the buyer behaviour of their parents in the food industry", Young Consumers, Vol. 11 No. 1, pp. 77-89.

Peter, J.P. and Olson, J.C., 2010. Consumer Behavior \& Marketing Strategy. 9th ed. New York: McGraw-Hill

Rettie, R. and Brewer, C. (2000), "The verbal and visual components of package design", Journal of Product and Brand Management, Vol. 9 No. 1, pp. 56-70.

Robertson, G.L. (1990) "Good and bad packaging: who decides?", Asia Pacific International Journal of Business Logistics, Vol. 3 No. 2, pp. 37-40.

Romaniuk, J. and Nenycz-Thiel, M. (2013), "Behavioral brand loyalty and consumer brand associations", Journal of Business Research, Vol. 66, pp. 67-72.

Rundh, B. (2005), "The multi-faceted dimension of packaging marketing logistic or marketing tool?", British Food Journal, Vol. 107 No. 9, pp. 670-684.

Rundh, B. (2009), "Packaging design: creating competitive advantage with product packaging", British Food Journal, Vol. 111 No. 9, pp. 988-1002.

Sara, R. (1990), "Packaging as a retail marketing tool", International Journal of Physical Distribution \& Logistics Management, Vol. 20 No. 8, pp. 29-30.

Schiffman, L.G. and Kanuk, L.L. (2004), Consumer Behavior, 8th ed., Pearson Education, Prentice-Hall, Upper Saddle River, NJ.

Sekaran, U., 2003. Research Methods for Business: A Skill-Building Approach. 4th ed. New York: John Wiley \& Sons, Inc.

Shenkar, O. (2010), "Copycats: how smart companies use imitation to gain a strategic edge", Viewpoint, Vol. 26 No. 10 , pp. 3-5.

Silayoi, P. and Speece, M. (2004), "Packaging and purchase decisions: An exploratory study on the impact of involvement level and time pressure", British Food Journal, Vol. 106 No. 8, pp. 607-628.

Silayoi, P. and Speece, M. (2007), "The importance of packaging attributes: a conjoint analysis Approach", European Journal of Marketing, Vol. 41 No: 11/12, pp. 1495-1517.

Tsao, H.Y., Hsin, M., Pitt, L.F. and Caruana, A. (2005), "The foundation of a 'High Price - High Quality' inferential belief: a study among young buyers of mobile phones and notebooks", Asia Pacific Journal of Marketing and logistics, Vol. 17 No. 1, pp. 50-60 
Utami, S.P.S., 2015. Sengketa Merek, GS Yuasa Menang Lawan GiSi. Kompas, [online] 24 June. Available at: http://bisniskeuangan.kompas.com/read/2015/06/24/1323005/Sengketa.Merek.GS.Yuasa.Menang.Lawa n.GiSi [Accessed 24 June 2015].

Van Horen, F. and Pieters, R. (2012a), "When high similarity copycats lose and moderate similarity copycats gain: The impact of comparative evaluation", Journal of Marketing Research, Vol. XLIX pp. 83-91

Van Horen, F. and Pieters, R. (2012b), "Consumer evaluation of copycat brands: The effect of imitation type", Intern. J. of Research in Marketing, Vol. 29 pp. 246-255.

Van Horen, F. and Pieters, R. (2013), "Preference reversal for copycat brands: Uncertainty makes imitation feel good", Journal of Economic Psychology, Vol. 37 pp. 54-64.

Wang, E.S.T. (2013), "The influence of visual packaging design on perceived food product quality, value, and brand preference", International Journal of Retail and Distribution Management, Vol. 41 No. 10, pp. 805816.

Warlop, L. and Alba, J.W. (2004), "Sincere flattery: trade-dress imitation and consumer choice", Journal of Consumer Psychology, Vol. 14 No. 1-2, pp. 21-27.

Young, M.R., DeSarbo, W.S. and Morwitz, V.G. (1998), "The stochastic modeling of purchase intentions and behaviour", Management Science, Vol. 44 No. 2, pp. 188-204.

Zaichkowsky, J.L. (1995), Defending Your Brand Against Imitation, Quorum Books, Westport, CT. 